УДК 336.2

DOI https://doi.org/10.32837/yuv.v0i3.2200

\author{
А. Сазонова, \\ помічник судді \\ Касаційного адміністративного суду України
}

\title{
ВИКОНАННЯ ФІЗИЧНОЮ ОСОБОЮ, ЯКА ПРОВАДИТЬ НЕЗАЛЕЖНУ ПРОФЕСІЙНУ ДІЯЛЬНІСТЬ, КОНСТИТУЦІЙНОГО ОБОВ'ЯЗКУ ЩОДО СПЛАТИ ПОДАТКІВ І ЗБОРІВ
}

Вступ. Відповідно до ст. $67 \mathrm{Koн-}$ ституції України кожен зобов'язаний сплачувати податки і збори в порядку i розмірах, установлених законом. Усі громадяни щорічно подають до податкових інспекцій за місцем проживання декларації про свій майновий стан та доходи за минулий рік у порядку, встановленому законом [1]. Основні положення загальної податкової правосуб'єктності платників податків у частині їхніх обов'язків закріплені у ст. 16 Податкового кодексу (далі - ПК) України. Відповідно до визначеного п. 4.1 .1 ст. 4 ПК України принципу загальності оподаткування кожна особа зобов'язана сплачувати податки та збори, платником яких вона $є[2]$. Обов'язок сплачувати податки і збори - основний обов'язок платника податків, який закладає засади його правового статусу [3, с. 160]. Як і всі інші обов'язки платників податків, цей обов'язок з урахуванням специфіки податкових правовідносин спрямований на задоволення публічних інтересів [4, с. 56].

Питання, пов'язані з виконанням конституційного обов'язку сплачувати податки, досліджувались вітчизняними та зарубіжними науковцями, серед яких Д. Гетманцев, В. Голобородько, Л. Задорожня, С. Зотов, М. Кучерявенко, Л. Палюх, О. Пантюшов, M. Перепелиця, В. Попов, Р. Паславська, А. Савченко, Т. Сащихіна, С. Смирних, Л. Товкун, С. Тра- сковський тощо. Втім, особливості відповідних правовідносин за участю осіб, що здійснюють незалежну професійну діяльність, наразі досліджені недостатньо.

Постановка завдання. У статті планується дослідити специфіку виконання конституційного обов'язку сплачувати податки і збори фізичними особами, що здійснюють незалежну професійну діяльність.

Результати дослідження. Конституційний обов'язок щодо сплати податків не може мати абстрактний характер, отже, конкретним змістом наповнюється за наявності певних умов, передбачених законом. Фактично в податковому законодавстві розкриваються принципи i порядок виникнення, зміни, припинення i виконання податкового обов'язку [5, c. 194, 6-7].

Виконання податкового обов'язку забезпечується силою державного примусу, здійснюваного фіскальними органами. У контексті предмету нашого дослідження цей обов'язок пов'язується 3 юридичним фактом здійснення платником податків незалежної професійної діяльності, дохід від якої є об'єктом оподаткування. Останній розраховується шляхом зменшення суми скоригованого валового доходу звітного періоду на суму документально підтверджених витрат, необхідних для провадження їхньої незалежної професійної діяль- 
ності [2]. Предметом оподаткування в даному випадку виступає ефективна незалежна професійна діяльність, результатом якої є формування активів у грошовій матеріальній і нематеріальній формах.

Оскільки відповідно до п. 178.3 ст. 178 ПК України [2] в разі неотримання довідки про взяття на облік особою, яка провадить незалежну професійну діяльність, об'єктом оподаткування $є$ доходи, отримані від такої діяльності без урахування витрат, специфіка об'єкту і предмету оподаткування зумовлює особливості реєстрації особи, яка здійснює незалежну професійну діяльність, як платника податків. Так, п. 178.1 ст. 178 ПК України передбачено, що особи, які мають намір здійснювати незалежну професійну діяльність, зобов'язані стати на облік у контролюючих органах за місцем свого постійного проживання як самозайняті особи та отримати довідку про взяття на облік згідно зі ст. 65 ПК України [2]. Особа, яка проводить незалежну професійну діяльність, повинна мати окремий рахунок для такої діяльності, який відрізняється від його особового рахунку як фізичної особи. Особові рахунки для ведення незалежної професійної діяльності використовувати заборонено (п. 14 розд. I Інструкції про порядок відкриття та закриття рахунків клієнтів банків $з$ постановою Національного банку України від 12.11.2003 p. № 492 [8]).

Базою оподаткування для осіб, що провадять незалежну професійну діяльність, є прибуток, який визначається скоригованим кількісним виразом, отриманим унаслідок різниці між доходами і видатками, тобто в термінології ПК України це «чистий оподатковуваний дохід» [2]. Доходом вважається зарахування грошей на рахунок, отримання готівки, отримання безкоштовних товарів, робіт, послуг, списання боргів, тоді як витратами вважають оплачені й документально підтверджені витрати, пов'язані $з$ незалежною професійною діяльністю (п. 178.3 ПК України). Визначенню складу таких витрат присвячені, зокрема, узагальнюючі податкові консультації, затверджені наказами Державної податкової служби України від 24.12.2012 р. № 1185 [9], Міністерства доходів і зборів України від 30.12.2013 р. № 884 [10] та від 30.12.2013 р. № 885 [11]. При цьому судова практика [12-18] підкреслює як специфіку нарахування податків у випадках, коли платник податків здійснює незалежну професійну діяльність, так і невичерпний характер переліків витрат указаних осіб, пов'язаних 3 їньою незалежною професійною діяльністю, що наведені в нормативних актах.

Платник податків, який здійснює незалежну професійну діяльність, самостійно визначає необхідну суму податку. Цей обов'язок платника податків реалізується шляхом подання декларації про прибуток до податкового органу у визначені законодавством терміни. Обчислення суми податку, що підлягає сплаті, здійснюється платником податків з урахуванням його об'єкта, податкової ставки, податкової пільги, предмета, бази, одиниці оподаткування, джерела, методів, термінів і способів сплати податку і особливостей податкового режиму, тобто всіх необхідних елементів, які становлять правовий механізм оподаткування. Фізичні особи, які провадять незалежну професійну діяльність, подають декларацію за результатами звітного року відповідно до розділу IV ПК України у строки, передбачені для платників податку на доходи фізичних осіб, в якій поряд із доходами від провадження незалежної професійної діяльності мають зазначати інші доходи 3 джерел ї походження з України та іноземні доходи (п. 178.4 ст. 178 ПК України) [2; 19]. Декларація має подаватися платником податків незалежно від того, виникло у звітному періоді податкове зобов'язання чи ні, 
тобто не в безпосередньому зв'язку зі станом його незалежної професійної діяльності. Ще одна умова виконання податкового обов'язку - це дотримання термінів подачі декларації та іншої податкової звітності. Таке виконання вважається своєчасним, якщо платник податків сплатив податок до закінчення терміну сплати, встановленого законодавством.

З 01.01.2021 р. фізичні особи складають і подають податкову декларацію про майновий стан і доходи (далі декларація) за формою, затвердженою наказом Мінфіну України від 02.10 .2015 р. № 859 [20]. Відповідно до п. 4 наказу Мінфіну України від 17.12 .2020 р. № 783, декларація в редакціï цього наказу подаватиметься з 01.01.2022 р. [21]. Відповідно до п. 179.9 ст. 179 ПК України бланки декларацій безоплатно надаються контролюючими органами платникам податку за запитом та є загальнодоступними для населення [2].

Платник податків - фізична особа, в тому числі й така, що провадить незалежну професійну діяльність, подає декларацію за звітний податковий період у встановлені ПК України строки до контролюючого органу за своєю податковою адресою (п. 45.1 ст. 45 ПК України) і може мати одночасно не більше однієї податкової адреси. У разі проживання не за місцем реєстрації декларація має подаватися до контролюючого органу за місцем реєстрації згідно з паспортними даними. У разі якщо фізична особа знята з реєстрації за однією адресою, але ще не зареєстрована за іншою, декларація подається до податкового органу за попередньою податковою адресою [2].

Податкова декларація про майновий стан і доходи подається за вибором платника податків, який здійснює незалежну професійну діяльність, до 2 серпня 2021 року в один із таких способів: особисто або уповноваженою на це особою; надсилається поштою $з$ повідомленням про вручення та 3 описом вкладення; засобами електронного зв'язку в електронній формі 3 дотриманням вимог законів щодо електронного документообігу [2]. Платник податку - фізична особа, що провадить незалежну професійну діяльність, який зобов'язаний подати декларацію, визначити та сплатити свої податкові зобов'язання, сплачує за кодами бюджетної класифікаціі: «11010500» - «податок на доходи фізичних осіб, що сплачується фізичними особами за результатами річного декларування» $(18 \%)$; «11011001» - «військовий збір, що сплачується за результатами декларування» $(1,5 \%)[22]$.

П. 5 ч. 1 ст. 4 Закону України «Про збір та облік єдиного внеску на загальнообов'язкове державне соціальне страхування» передбачає, що особи, які провадять незалежну професійну діяльність та отримують від неї дохід, $€$ платниками єдиного соціального внеску (ЄСB) [23], який нараховується і сплачується щоквартально за даними Книги обліку доходів і витрат [24] (у 2021 р. мінімальний страховий внесок 3 ЄСВ становитиме: 3 січня по листопад 6000 × 22\% = 1320 грн, за грудень - 1430 грн, тоді як максимальна база для нарахування ЄСB становитиме: 3 січня по листопад 90000 грн, у грудні - 97500 грн) [25]. Особи, які провадять незалежну професійну діяльність, не зобов'язані сплачувати мінімальний розмір ЄСB за місяці, в яких ними не отримано доходу. Також звільнено від сплати осіб, які провадять незалежну професійну діяльність, якщо вони отримують пенсію за віком, за вислугу років, є особами $з$ інвалідністю або досягли віку, встановленого ст. 26 Закону України «Про загальнообов'язкове державне пенсійне страхування» [26], та отримують пенсію чи соціальну допомогу [27].

Особи, що здійснюють незалежну професійну діяльність, які мають найманих працівників, за I кв. 2021 р. подають розрахунок за формою 1 ДФ 
з урахуванням змін, внесених наказом Міністерства фінансів України від 15.12.2020 р. № 773 [28].

Під час виплати суб'єктами господарювання - податковими агентами фізичним особам, які провадять незалежну професійну діяльність, доходів, безпосередньо пов'язаних 3 такою діяльністю, податок на доходи в джерела виплати не утримується в разі надання такою фізичною особою копіі свідоцтва про взяття іï на податковий облік як фізичної особи, яка провадить незалежну професійну діяльність. Це правило не застосовується в разі нарахування (виплати) доходу за виконання певної роботи та/ або надання послуги згідно з цивільно-правовим договором, відносини за яким установлено трудовими відносинами, а сторони договору можуть бути прирівняні до працівника чи роботодавця відповідно до п.п. 14.1.195 та 14.1.222 п. 14.1 ст. 14 ПК України [29]. У цьому випадку фізична особа включає такий дохід до річної податкової декларації та самостійно нараховує і сплачує податок на доходи фізичних осіб [30]. Також слід зауважити, що оскільки особи, які провадять незалежну професійну діяльність, не $є$ в рамках цієї діяльності найманими працівниками і не отримують дохід у вигляді заробітної плати, такі особи не мають права на застосування податкової знижки [31].

Невиконання податкового обов'язку надає податковому органу право перейти до процедури примусового стягнення податку. Початок цієї процедури - напрям вимоги про сплату податку. Невиконання податковим органом обов'язків по напряму вимоги про сплату податку буде означати, що платник податку не мав можливості добровільно виконати обов'язок зі сплати податку, що $€$ порушенням процедури стягнення. Відповідальність за несвоєчасне подання податкової деклараціï передбачена п. 120.1 ст. 120 ПК України [2] та ст. $164^{1}$ Кодексу
України про адміністративні правопорушення [32].

Моментом виконання податкового обов'язку необхідно визнавати момент, коли вилучення частини майна платника податків, призначеної для сплати в бюджет як податку, фактично відбулося. Таке вилучення відбувається в момент списання банком $з$ розрахункового рахунка платника податку відповідних коштів на сплату податку або сплати платником податку коштів у касу банку. Після цього майно платника податків уже вилучено, а податок сплачений [33]. Обов'язок щодо сплати податку припиняється у випадку: належного виконання податкового обов'язку, в т.ч. й взаємозаліку з бюджетом, смерті платника податків або визнання його померлим у порядку, встановленому цивільним законодавством; втрати ознак, що визначають особу як платника податків, тобто припинення здійснення незалежної професійної діяльності. В юридичній літературі також розроблено підстави для зміни податкового обов'язку, до яких відносять зміни податкового законодавства, зміну термінів сплати податку, залік надміру сплачених сум податків тощо [34-36], адже, як справедливо зазначає Л. Товкун, тільки за наявності повної сукупності елементів правового механізму податку обов'язок платника податків зі сплати податку може вважатися виконаним у повному обсязі [37].

Висновки. Чинне законодавство визначає перелік обов'язків платників податків, які мають бути виконані особами, котрі провадять незалежну професійну діяльність. Зміст податкового обов'язку полягає в наявності у них зобов'язання сплатити податок, законно встановлений, правильно обчислений, у певному розмірі, 3 дотриманням встановленого порядку і строків сплати. Виникнення обов'язку сплачувати податки і збори в осіб, що здійснюють незалежну професійну діяльність, законодавець 
пов'язує з юридичним фактом виникнення у зобов'язаної особи об'єкта оподаткування - прибутку від незалежної професійної діяльності.

На сучасному етапі необхідно вибудовувати державну податкову політику щодо осіб, які здійснюють незалежну професійну діяльність, таким чином, аби, з одного боку, забезпечити наповнення бюджету, а 3 іншого - не зумовити зникнення у платника податків бажання займатися незалежною професійною діяльністю. Наразі оподаткування незалежної професійної діяльності в Україні $€$ досить обтяжливим і таким, що не сприяє розвитку професійної діяльності (фіскальне навантаження доходів від незалежної професійної діяльності становить близько $42 \%$ ), крім того, існує низка правових колізій, яка ускладнює виконання особою, яка провадить незалежну професійну діяльність, конституційного обов'язку щодо сплати податків і зборів. Тож надалі підлягає впорядкуванню публічно-правовий вплив фіскальної політики на приватно-правові відносини $з$ метою забезпечення стабільності конституційних правовідносин в податковій сфері.

Статтю присвячено дослідженню особливостей виконання конституційного обов'язку сплачувати податки і збори фізичними особами, що здійснюють незалежну професійну діяльність.

Чинне законодавство визначає перелік обов'язків платників податків, які мають бути виконані особами, котрі провадять незалежну професійну діяльність. Зміст податкового обов'язку полягае в наявності у них правового обов'язку сплатити податок, законно встановлений, правильно обчислений, у певному розмірі, з дотриманням встановленого порядку $i$ строків сплати. Виникнення обов'язку сплачувати податки $i$ збори в осіб, що здійснюють незалежну професійну діяльність, законодавець пов'язуе з юридичним фактом здійснення платником податків незалежної професійної діяльності, дохід від якої $є$ об'єктом оподаткування. Останній розраховується шляхом зменшення суми скоригованого валового доходу звітного періоду на суму документально підтверджених витрат, необхідних для провадження їхної незалежної професіиної діяльності, відповідно до $n .178 .3 \mathrm{~cm} .178$ ПК України. Предметом оподаткування в даному випадку виступае ефективна незалежна професійна діяльність, результатом якої $\epsilon$ формування активів.

Особа, що здійснюе незалежну професійну діяльність, зобов'язана сплачувати податок на доходи фізичних осіб, військовий збір та єдиний соціальний внесок. Платник податків, який здійснюе незалежну професійну діяльність, самостійно визначае необхідну суму податку $i$ подає податкову декларацію до податкового органу у визначені законодавством терміни.

Обов'язок щзодо сплати податку припиняється у випадку: належного виконання податкового обов'язку, в т.ч. й взаємозаліку з бюджетом, смерті платника податків або визнання його померлим у порядку, встановленому иивільним законодавством; втрати ознак, що визначають особу як платника податків, тобто припинення здійснення незалежної професійної діяльності.

Наразі фіскальне навантаження доходів від незалежної професійної діяльності становить близько $42 \%$, що не сприяє розвитку професійної діяльності. Також існуе низка правових колізій, яка ускладнюе виконання конституційного обов'язку щзодо сплати податків $і$ зборів.

Ключові слова: фізична особа, незалежна професійна діяльність, оподаткування, конституційний обов'язок. 
Sazonova A. FULFILLMENT OF A CONSTITUTIONAL OBLIGATION TO PAY TAXES AND FEES BY AN INDIVIDUAL WHO CARRIES OUT INDEPENDENT PROFESSIONAL ACTIVITY

The article is devoted to the study of the peculiarities of fulfillment of the constitutional obligation to pay taxes and fees by individuals engaged in independent professional activity.

The current legislation defines the list of duties of taxpayers to be performed by persons engaged in independent professional activity. The content of the tax liability is that they have a legal obligation to pay the tax, legally established, correctly calculated, in a certain amount, in accordance with the established procedure and terms of payment. The legislator connects the occurrence of the obligation to pay taxes and fees to persons engaged in independent professional activity with the legal fact of the taxpayer's independent professional activity, the income from which is subject to taxation. The latter is calculated by reducing the amount of adjusted gross income for the reporting period, the amount of documented expenses necessary for their independent professional activity in accordance with paragraph 178.3 of Art. 178 of the Civil Code of Ukraine. The subject of taxation in this case is an effective independent professional activity, the result of which is the formation of assets in monetary tangible and intangible forms.

A person engaged in independent professional activity is obliged to pay personal income tax, military duty and a single social contribution. Such taxpayer determines the required amount of tax and submits a tax return to the tax authority within the time limits specified by law. The obligation to pay the tax is terminated in the case of: proper performance of the tax obligation, including and offsetting against the budget, the death of the taxpayer or his death in the manner prescribed by civil law; loss of characteristics that define a person as a taxpayer, ie, the cessation of independent professional activity. Currently, the fiscal burden of income from independent professional activity is about $42 \%$, which does not contribute to the development of professional activity. There are also a number of legal conflicts that make it difficult to fulfill the constitutional obligation to pay taxes and fees.

Key words: individual, independent professional activity, taxation, constitutional duty.

\section{Література}

1. Конституиія

$U R L: h t t p s: / / z$ laws/show/254\%Do\%BA 96-\% D0\% B2\% D1\%80\#Text

2. Податковий кодекс України. URL: https: / / zakon.rada.gov.ua / laws / show / 2755-17

3. Налоговое право : учебник для вузов. Москва : Альпина Паблишер, 2015. $796 \mathrm{c}$.

4. Химичева Н.И. Налоговое право: учебник. Москва, 1997. 336 с.

5. Гетманцев Д.О. Фінансово-правове зобов'язання як окрема категорія фінансового права. Київ : Юрінком Інтер, 2011. $368 \mathrm{c}$.

6. Новоселова Л.А., Рожкова M.A. Недействительность сделок и налоговые обязанности. URL: https: / / wrere.lawmix.ru/comm / 4165

7. Пепеляев С.П. Деловая цель сделки. URL: http: / / base.garant.ru / 5373531/

8. Інструкція про порядок віәкриття та закриття рахунків клієнтів банків з постановою НБУ від 12.11.2003 р. № 492. URL: https: / / zakon.rada.gov.ua / laws / show/z1172-03\#Text

9. Про затвердження Узагальнюючої податкової консультаціі щодо деяких питань оподаткування фізичних осіб, які провадять незалежну професійну діяльність (приватних нотаріусів, адвокатів). Наказ ДПС України вї 24.12.2012 р. № 1185. URL: https: / / tax.gov.ua/zakonodavstuo/ podatkove-zakonodavstvo/ 
uzagalnyuyuchi-podatkovikonsultatsii/62191.html

10.Про затвердження Узагальнюючої податкової консультаціi щзодо витрат приватного нотаріуса. Наказ Міністерства доходів $і$ зборів України віة 30.12.2013 p. № 884. URL: https: / / zakon.rada.gov.ua/rada / show / v0884810-13\#Text

11.Про затвердження Узагальнюючої податкової консультациї щзодо переліку витрат адвокатів, які надають безоплатну вторинну правову допомогу Наказ Міністерства доходів $i$ зборів України від 30.12.2013 p. № 885. URL: https: / / tax.gov.ua/zakonodavstvo/ podatkove-zakonodavstuo/nakazi/ 62985.html

12. Постанова

ховного $\mathrm{Cy \partial y}$ 09.03.2021 p.yсnравi.№ 819/1104/16.URL: https: / / zakononline.com.ua/courtdecisions / show / 95382434

13. Постанова

ховного Суду України Вер 28.04.2021 p. у справі № 813/712/15. URL: https: / / zakononline.com.ua/courtdecisions / show / 89013283

14. Постанова

23.12 .2019 p.y cnpaвi № 815/3145/15UR:

https: / / zakononline.com.ua/courtdecisions / show/86594987

$$
\text { 15. Постанова }
$$

ховного Суду України від 15.08.2019 p. у справі № 816/341/16. URL: https: / / zakononline.com.ua/courtdecisions / show / 83692112

16. Постанова Верховного Суду України від 28.05.2019 p. y справі № № 826/24060/15. URL: https: / / zakononline.com.ua/courtdecisions/show/82020185

$$
\text { 17. Постанова Верховного }
$$

Суду України від 26.02.2019 p. y справі № 820/12016/15. URL: https: / / zakononline.com.ua/courtdecisions / show / 80316668

18. Постанова Південно-Західного апеляційного господарського суду віә 11.02.2020 p. у справі № 902/519/18. URL: https: / / zakononline.com.ua/courtdecisions / show / 87651978

19. 3а матеріалами ГУ ДПС y Волинській області. URL: https: / / ibuhgalter.net/ru/ news / 11424

20. Про затвердження форми податкової декларації про майновий стан $i$ доходи та Інструкиії щзодо заповнення податкової деклараиіі про майновий стан $i$ доходи : Наказ Мінфіну України від 02.10.2015 p. № 859. URL: https: / / zakon.rada.gov.ua/laws / show / z1298-15\#Text

21. Про внесення змін до наказу мінфіну України від 02 жовтня 2015 року № 859 : Наказ Мінфіну України віة 17.12.2020 p. № 783. URL: https: / / zakon.rada.gov.ua/laws/ show / z1295-20\#n2

22. Деклараційна кампанія 2021. URL: https://tax.gov.ua/deklaratsiynakampaniya-2021 / granichni-stroki-splati

23. Про збір та облік єдиного внеску на загальнообов'язкове державне соиіальне страхування : Закон України. URL: https://zakon.rada.gov.ua/laws/ show / 2464-17\#Text

24. Про затвердження форми Книги обліку доходів і витрат, яку ведуть фізичні особи - підприємиі, крім осіб, щзо обрали спрощену систему оподаткування, $i$ фізичні особи, які провадять незаленну професійну діяльність, та Порядку ї ведення : Наказ Міністерства доходів $i$ зборів України. URL: https://zakon.rada.gov.ua/laws / show / z1686-13\#Text

25. Розміри ECB-2021. URL: https: / / www.golovbukh.ua / article / ru/7868-esv-2020-budut-li-izmeneniya-voplate-i-stavkah

26. Про загальнообов'язкове державне пенсійне страхування : Закон України. URL: https://zakon.rada.gov.ua/laws / show / 1058-15\#Text

27. ЄСВ-покращення

01.01 .2021 p. URL: http://kmp.ua/ uk/analytics / infoletters / the-unifiedsocial-contribution-improvement-fromjanuary-01-2021

28. Роз'яснення про особливості декларування доходів, отриманux у 2020 роціi. URL: https:/ / mostivska.dosvit.org.ua/ news / rozyasnennya-pro-osoblivostideklaruvannya-dohodiv-otrimanih-u-2020rotsi-2021-02-10

29. Оподаткування незалежної професійнӧ діяльності. URL: http: / / tr.sfs.gov.ua/media-ark/newsark/print-82400.html

30. Незалежна професійна діяльність. URL: http:// wrew.visnuk.com.ua/ua/ pubs / id / 538

31. Індивідуальна податкова консультація: лист ДПС України від 16.04.2021 p. 


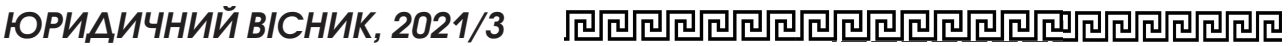

№ 1572/IПK/99-00-04-03-03-09. URL: https: / / www.profiwins.com.ua/uk/ letters-and-orders / ipk/16955-1572-21.html

32. Кодекс України про адміністративні правопорушення. URL: https: / /zakon.rada. gov.ua/ laws/ show/80731-10\#Text

33. Зотов С. Конституционная обязанность платить налоги - детерминанта правового статуса налогоплаmeльщuка. URL: https: / / cyberleninka.ru/ article/n/konstitutsionnaya-obyazannost-platit-nalogi-determinanta-pravovogo-statusa-nalogoplatelschika

34. Пантюшов О.В. Обязанность налогоплательщика по уплате нало- гов. и сборов. Адвокат. 2012. № 3. C. 53-58.

35. Кучерявенко Н.П. Основы налогового права. Харьков : Легас, 2003. $584 \mathrm{c}$.

36. Перепелиия М.О. Правове регулювання статусу платників податків i зборів в Україні : дис. ... канд. юрид. наук. Харків : Нац. юрид. акад., 2001. C. 50-51.

37. Товкун Л.В. Налоговая обязанность и ее исполнение плательщиками налога на прибыль. URL: http: / / library.nlu.edu.ua/poln_text / PROBLEM/Pr_zak72.htm\#Tовкун 